\title{
QUESTIONS AND PROBLEMS OF TRANSLATION OF TECHNICAL TERMS OF TEXTILE AND LIGHT INDUSTRY
}

\author{
Karimova Nodirakhon Abdurashidovna, Andijan State University, Faculty of Foreign Languages, \\ teacher of German at the Department of German Language and Literature, Andijan, Republic of \\ Uzbekistan
}

Aburakhmanov Abdurashid, Associate professor of the department "Hayot faoliyati havfsizligi", Andijan Machine-Building Institute, Andijan, Republic of Uzbekistan

DOI: https://doi.org/10.31435/rsglobal_conf/25122020/7314

Abstract. The problems coming out of compiling technical terminological dictionaries in the field of textile industry are given in the article.

Keywords: terminological dictionary, functional style, lexical-semantic system, unambiguity.

The progress of science is inevitably accompanied by the appearance of special words to designate the objects under study. The development of technology in the world gives rise to its own special words. And also for the introduction of innovations in technology and in other fields of science, first of all, they give rise to the requirements for the creation of two or multilingual terminological dictionaries. But this phenomenon itself is universal.

What is a term? The terminological dictionary should provide an interpretation of the terms. The concept of "term" has been studied in detail by the leading Russian lexicographer F.P. Sorokoletov. He emphasizes that "a term is not a special word, but only a word in a special function," in the function of naming a special concept, the name of a special object or phenomenon. While the "everyday", nonspecial word is related to a well-known, "ordinary" object, the term is related to an object known to a limited circle of specialists. A new term is born in connection with the emergence of new knowledge, with the discovery of a previously unknown object. However, not everything proposed is accepted for use and not every term is preserved even for decades. In this regard, the term should be considered as a historically established, in other words, an established unit of the terminological system. The compilers of new terminological systems are often carried away by the idea of making the terms unambiguous, striving to ensure that they have neither synonyms nor homonyms that make it difficult for specialists to communicate with each other. If we accept terminology as a system, then it seems obvious that elements with different principles of lexicographic description of a word. Since each word "homonym" is included in its functional-style system, then when interpreting them, unequal signs of semantic definition are relevant. However, being subsystems of one and the same national language, these functional and stylistic spheres closely interact with each other, sometimes creating very significant difficulties. In these cases, the role and responsibility of the lexicographic work increases.

Since the term is considered part of the lexical-semantic system or lexical unit, it obeys all the laws of general linguistics and has a special place in the language. A word, a lexical unit, is the basis for the names of new names; its next task is to form a term. On the basis of the laws of linguistics, the terms formed on the lexical layer to a certain extent retain their denotative meaning, but this meaning is specialized. Words that are not terms express tangible information about the subject. This information can be emotionally expressively colored. The alphabetic organization of the material plays a subordinate role. Therefore, compiling a multilingual vocabulary is a difficult task.

The definition of an alternative between the terms of different languages, or rather the translation of a term from one language to another, is an important issue of terminology. To investigate the proportionality of the terms of the German language of the textile industry with the terms of the Russian and Uzbek languages, we divide them into the following groups:

1.Terms have proportionality in German, Russian and Uzbek languages. The terms in this group have the same meaning and form.

$\begin{array}{lcc}\text { German language } & \text { Russian language } & \text { Uzbek language } \\ \text { Satin m,-s,-s } & \text { сатин } & \text { Satin } \\ \text { Viskose f } & \text { вискоза } & \text { Viskoza(kimyoviy tola) } \\ \text { Chiffon[шифо:] } & \text { шифон } & \text { Shifon } \\ \text { Crepe de chine m,-s } & \text { крепдешин } & \text { Krepdeshin }\end{array}$




\section{Armure f aрмюр Armyur \\ Gabardine $\mathrm{f}$ Габардин Gabardin (jun gazlama turi)}

Symbolic: AL1 + AL2 + AL3 = AL1 + AL2 + A

Translations of this kind of terms in German have proportionality in the following two languages. But it should be noted, since the dictionary is trilingual and as the main language is German, most of the terms in the German language are not of German origin. For example, the word Satin m, -s, -s is Arabic, and the word Crepe de chine m, -s is of French origin. The source is the same and is used in all languages. Since reciprocal words retain their form and meaning. or phrase.

2. The terms are the same in German and Russian, in Uzbek it is conveyed by a different term
German language
Russian language
Uzbek language

Rollenkarte $\mathrm{f}$ роливокая карта

G'altak kartasi

Appretur f 1.аппретура, аппретурирование, отделка 1.pardozlash gazlama yoki teriga maxsus ishlov berish Symbolic: AL1 + AL2 + BL3 = AL1, AL2, BL3

3. In German, the term a in Russian and Uzbek is given by another word or phrase.

\section{German language. \\ Pausferfahren n,-s}

\author{
Uzbek language \\ kalkalash,kalkaga \\ ko`chirish
}

Valka

Durchwalke $\mathrm{f} \quad$ Валка

Symbolic: AL1 + B L2 + BL3 = AL1, BL2, BL3

4. This is a group of terms that do not comply with the above requirements. They are translated into the next two languages using presentation.
German language
Russian language
Narben f,-s
лицевая сторона
Durchzug $\mathrm{m}$
Проборка в ремиз.
Uzbek language
charmning o'ng old tomoni
Shodaga terish

Symbolic: $\mathrm{A}+\mathrm{B}+\mathrm{C}=\mathrm{ABC}$

5. In all three languages are the same, but the meaning is different. This case is very rare.

So, although the requirements for unambiguity and the absence of synonyms within the same terminological system, correct orientation to the object, are imposed on the "ideal" term, but modern terminology does not fit into these strict frameworks. The presence of synonymy-duplication, polysemy, multilateral connections of terms with words of a common language make an ideal terminological system virtually unattainable.

The presence of Russian equivalents helps them to compare their own still unsteady ideas about the meaning of Uzbek terms with their real scientific meaning.

In conclusion, I would like to note that terminology and lexicography are an urgent issue of today, the scientific solution of this issue is important for the scientific and technical, as well as economic and social development of our country.

\section{REFERENCES}

1. В.В. Виноградов «основные типы лексических значений слов. В.Я,1953№5, С.6.

2. В.В. Виноградов «Русский язык». М.Л, 1947, С.12-13

3. Сороколетов Ф. П. Общая и учебная лексикография. Л., 1985.

4. Годер Н.Н.О логической структуре понятий выраженного словосочетанием - В кн.: Логикограмматические очерки. М., 1961

5. Умарходжаев М.Э. Очерки по современной фразеографии.Т.:1977

6. Сороколетов Ф. П. История военной лексики в русском языке. Л., 1970.

7. Назаров К.Н., Тоштемиров Н. Тукимачилик ва тикувчиликда руссча узбекча атамалар лугати» Андижан 1995 